DOI 10.22363/2313-2329-2020-28-4-765-777

UDC 331

Research article

\title{
Micro-business in France: specificity, role in the national economy, system of state support
}

\author{
Zhanna N. Komissarova \\ Moscow State Institute of International Relations (University) of \\ the Ministry of Foreign Affairs of Russia (MGIMO University) \\ 76 Vernadskogo Ave, Moscow, 119454, Russian Federation
}

\begin{abstract}
Micro-business functioning has a significant impact on the state of the economy and social sphere of any country. The French pattern is noteworthy because a country, that had been aiming at the development of large groups for a long time earlier, only in two decades managed to build a successful system of governmental support for micro-business that includes both specific and common measures for small and medium-sized enterprises (SMEs). The study attempts to identify current development trends of the micro-business in France and also to analyse the effectiveness of the state support system provided for the activities of the considered category of the economic entities. Depending on the nature of the subject matter, the author used such methods and approaches of scientific knowledge as induction and deduction, analysis and synthesis, system-structural, comparative and statistical analysis. The study analyses in detail the current development trends of the microbusiness in France, including its sectorial and regional specifics, estimates the contribution of microenterprises to the economic and social development of the country and deeply examines the system of state support. Micro-enterprises take an important place in the French economy by providing one fifth of the employment in the country and the same share of value added. Meanwhile, microenterprises are quite weakly oriented towards export because their activities are targeted mainly at the local markets and concentrated in the services sector. Micro-enterprises contribute little to research and development (considering the percentage of total expenditure on research and development and the percentage of total employment in scientific research sector). However, micro-business remains an absolute leader in terms of research and development intensity by spending almost one third of its turnover on researches and considering the share of the direct financial assistance from the state in total expenditures on scientific researches. To date, a sufficiently effective system of public support to micro-business has been formed in France. Apart from providing financial assistance, the system includes substantial tax benefits and simplified taxation schemes, easy reporting system and simple procedures for filing tax return, facilitated social regime, simplification of major bureaucratic formalities and strong information support in all stages of functioning of an enterprise.
\end{abstract}

Keywords: economy of France, micro-enterprise, role of micro-business in national economy, system of state support for micro-business, micro-enterprise regime, tax exemption

\section{Introduction}

Review of experience in micro-business functioning of the particular countries is topical since micro-enterprises have a significant impact on the state of

(C) Komissarova Zh.N., 2020

(c) (i) This work is licensed under a Creative Commons Attribution 4.0 International License https://creativecommons.org/licenses/by/4.0/ 
the economy and social sphere. By being a significant source of employment, they provide reduction of unemployment, improved human welfare and reduced social burden on the national budget.

The important directions of French policy in the post-war period were the implementation of the state program aimed at strengthening the country's political and economic power, the promotion of production concentration and the centralization of capital. One of the major results of this policy became a rapid development of the large groups and growth of their international economic activities from the mid1970s. Nevertheless, the number of self-employed workers was nearly halved from the mid-1970s to the mid-2000s. The situation began to change in the late 2000s due to the establishment of a specific regime for micro-entrepreneurs. The French model is noteworthy because a country, aimed at the development of large groups for a long time earlier, has managed to build a successful system of governmental support for micro-business only in two decades. The system includes both specific and common measures for small and medium-sized enterprises (SMEs).

\section{Review of the literature}

General issues related to the research are widely discussed in scientific circles. The theoretical aspects of SMEs (including micro-business) functioning are reflected in a number of works both Russian (Barinova et al., 2019) and foreign (Arlotto et al., 2011; Marniesse, 2000) economists. The matter of its role estimation for the national economy and social sphere are reviewed by N.L. Vlasova (Vlasova, 2015), N.V. Zakharova, A.V. Labudin (Zakharova, Labudin, 2017), J. Arlotto, A. Cyr, O. Meier, J. Pacitto (Arlotto et al., 2011), K. Kushnir, M. Mirmulstein, R. Ramalho (Kushnir et al., 2010) et al. The study of the activities within the frames of country-specific circumstances and system of state support for small business entities is conducted in the works of N.V. Zaharovoj, A.V. Labudina (Zakharova, Labudin, 2017), Zh.N. Komissarovoj (Komissarova, 2015), V.A. Barinovoj, S.P. Zemcova, A.Yu. Knobel, A.N. Loshchenkovoj (Barinova et al., 2019), K. Kushnir, M. Mirmulstein, R. Ramalho (Kushnir et al., 2010) et al. At the same time the development specifics of the French microbusiness as well as the system of its state support are insufficiently considered in the present literature, that is why the author referred mainly to the official sources while analyzing a whole range of aspects on the research. The main sources of information for this study were statistical data and publications of the National Institute of Statistics and Economic Studies (French: Institut national de la statistique et des études économiques, INSEE) and the Organizations for the Collection of Social Security and Family Benefit Contributions (French: la Caisse nationale des Urssaf, Acoss); publications from the European Commission, the Ministry of Higher Education, French Science and Innovations; materials from the Chamber of Industry and Commerce and Social Security of Self-Employed Workers Fund (French: Sécurité sociale pour les indépendants, SSI); both European and national general documents.

\section{Methods and approaches}

Depending on the nature of the subject matter, the author used such methods and approaches of scientific knowledge as induction and deduction, analysis and synthesis, system-structural, comparative and statistical analysis. 


\section{The results of the study}

Micro-enterprise in France: definition, specifics, role in the national economy. In France, micro-enterprise economic category was introduced the Decree No. 2008-1354 of 18 December $2008^{1}$ that defined four enterprise groups according to the Law on the Modernization of the Economy No. 2008-776 of 4 August $2008^{2}$. It established the qualification criteria in order to refer an economic entity to a particular criteria group (number of employees, annual turnover or total balance, whereas the first criterion is the key point). The decree is based on the EU common approach on the definitions of micro, small and medium-sized enterprises stated in the EU commission recommendations 2003/361/EC of 6 May 2003 (Barinova et al., 2019; Goffee, Scase, 2016). Micro-enterprise, thus, must satisfy the following conditions: to employ less than 10 persons and to have either an annual turnover or a total balance sheet not exceeding 2 million euro.

In legal terms, a micro-enterprise in France may be created in the form of individual enterprise (French: entreprise individuelle, EI), individual enterprise with limited responsibility (French: entreprise individuelle à responsabilité limitée, EIRL) or single-owner limited liability enterprise (French: entreprise unipersonelle à responsibilité limitée, EURL). The first two organizational and legal forms do not refer to the establishment of a company; such enterprises may be created only by a physical person and belong to a single person or a tax household. In the latter case, either a physical person or an entity may be the only partner, but only a physical person has access to the micro-enterprise tax regime (see later). ${ }^{4}$

In 2017 there were 3,7 million micro-enterprises with 2445 thousand employees $^{5}$ in France $(96 \%$ of all enterprises and 19\% of employment of the country). On average, there was one employee per a micro-enterprise, whereas $73 \%$ of micro-enterprises didn't have any employees, $13 \%$ of micro-enterprises had the only employee and $14 \%$ of micro-enterprises had two or more employees. ${ }^{6}$

According to the European statistics, in 2018 micro-business represented $95,5 \%$ of the total number of enterprises in France (for comparison, the same rate in the EU was generally at the level of $93 \%$ and in Germany, Belgium and the Netherlands - at the level of $82,0,94,6$ and 95,6\% respectively) ${ }^{7}$ (Zakharova, Labudin, 2017; Barinova et al., 2019).

${ }^{1}$ Décret $n^{\circ}$ 2008-1354 du 18 décembre 2008 relatif aux critères permettant de déterminer la catégorie d'appartenance d'une entreprise pour les besoins de l'analyse statistique et économique. Retrieved May 20, 2020, from https://www.legifrance.gouv.fr/affichTexte.do?cidTexte=JORFTEXT000019961059

${ }^{2}$ LOI n ${ }^{\circ}$ 2008-776 du 4 août 2008 de modernisation de l'économie. Retrieved May 20, 2020, from https://www.legifrance.gouv.fr/affichTexte.do?cidTexte=JORFTEXT000019283050

${ }^{3}$ Commission Recommendation of 6 May 2003 concerning the definition of micro, small and medium-sized enterprises. Retrieved May 22, 2020, from http://eur-lex.europa.eu/legal-content/EN/ TXT/PDF/?uri=CELEX:32003H0361\& from=EN

${ }^{4}$ Chambre de commerce et d'industrie. (n.d.). Les principes du regime micro-entrepreneur. Retrieved May 22, 2020, from https://www.cci.fr/web/auto-entrepreneur/le-regime-micro-entrepreneur

${ }^{5}$ INSEE. (n.d.). Data on market sector not considering enterprises within the financial and insurance sectors but including the entities that micro-enterprise tax regime. Les entreprises en France, Édition 2019. Retrieved May 27, 2020, from https://www.insee.fr/fr/statistiques/4256020

${ }^{6}$ Ibid.

${ }^{7}$ European Commission. (n.d.). Internal Market, Industry, Entrepreneurship and SMEs. Retrieved May 22, 2020, from https://ec.europa.eu/growth/smes/business-friendly-environment/performancereview_en\#annual-report 
The distribution of enterprises, employment, turnover, export and value added by different enterprise size categories in France is presented in Table 1.

Share of different categories of enterprises ${ }^{8}$ in the French production system in $2017, \%$

\begin{tabular}{lccccc}
\hline & \multicolumn{3}{c}{ Share of total rates of industry and service } \\
\cline { 2 - 6 } \multicolumn{1}{c}{ Enterprise size categories } & $\begin{array}{c}\text { In total } \\
\text { balance of } \\
\text { enterprises }\end{array}$ & $\begin{array}{c}\text { In total } \\
\text { employ- } \\
\text { ment }\end{array}$ & In turnover & In exports & $\begin{array}{c}\text { In value } \\
\text { added }\end{array}$ \\
\hline Micro-enterprises & 96,0 & 18,8 & 13,0 & 2,7 & 19,9 \\
$\begin{array}{l}\text { Small and medium-sized enterprises } \\
\text { (not including micro-enterprises) }\end{array}$ & 3,8 & 29,9 & 22,4 & 11,8 & 23,3 \\
Intermediate-sized enterprises & 0,2 & 25,1 & 30,3 & 31,9 & 26,0 \\
Large enterprises & 0,01 & 26,2 & 34,3 & 53,6 & 30,8 \\
Total & 100,0 & 100,0 & 100,0 & 100,0 & 100,0 \\
\hline
\end{tabular}

Source: the author's calculations based on data of the French National Institute of Statistics and Economic Studies.

The table indicates that micro-business provides around $20 \%$ of value added, $13 \%$ of turnover and only $2,7 \%$ of export, which is appropriate because microenterprise activities generally refer to the local markets and focused on provision of services for individuals, trade, artisanal activities and construction operations (Barinova et al., 2019). Overall, only $10 \%$ of micro-enterprises function in industry, whereas in construction operations and service sector work 18 and $72 \%$ of micro-enterprises respectively (for comparison: the same figures of the total population of enterprises are 24,10 and $66 \%$ respectively). ${ }^{9}$ It should be noted that micro-enterprises export only $3,9 \%$ of their production while small and mediumsized enterprises (except for micro-enterprises) export $10,5 \%$ of their production and the total number of enterprise categories exports collectively $19,3 \%$ of their production. ${ }^{10}$

By analyzing region-specific distribution of micro-business, it should be noted that while large and intermediate-sized enterprises are concentrated mainly in the Paris region Île-de-France and in the other industrially developed regions, SMEs (including micro-enterprises) function mainly in the south of the country and largely oriented on the sphere of hotel and restaurant business. Thus, $24 \%$ of

${ }^{8}$ There are four categories of enterprises according to the French statistics: micro-enterprises (which employ less than 10 persons and either have an annual turnover or a total balance sheet not exceeding 2 million euro), small and medium-sized enterprises (which employ less than 250 persons, either have an annual turnover not exceeding 50 million euro or a balance sheet total not exceeding 43 million euro), intermediate-sized enterprises which employ less than 5000 persons and either have an annual turnover not exceeding 1500 million euro or a balance sheet total not exceeding 2000 million euro. Large enterprises consist of enterprises that are not classified in the previous categories.

The national methodology doesn't consider data on financial and insurance sectors. Besides, data on enterprises in health, education and social activity, enterprises with micro-enterprise tax regime aren't considered while calculating.

${ }^{9}$ INSEE. (n.d.). Les entreprises en France, Édition 2019. Retrieved May 27, 2020, from https://www.insee.fr/fr/statistiques/4256020

${ }^{10}$ Ibid. 
the total employee number in province Provence-Alpes-Côte d'Azur, for instance, is occupied in micro-enterprise and in Corsica the rate reaches $38 \% .^{11}$

The large number of micro-enterprises in the southern regions of France is provided by a considerable concentration of persons employed in the liberal professions. For instance, there are 1996 practitioners per 100 thousand inhabitants in Provence-Alpes-Côte d'Azur region (which surpasses even the metropolitan area with the rate of 1945 specialists, whereas one fourth of the specialists works as micro-entrepreneurs). ${ }^{12}$

Table 2

Dynamics of value added and employment of varisized categories of industrial enterprises according to the level of knowledge-intensity in France and some other countries with a similar level of development in 2018

\begin{tabular}{|c|c|c|c|c|}
\hline & France & Germany & Belgium & The Netherlands \\
\hline \multicolumn{5}{|c|}{ Value added/Employment } \\
\hline \multicolumn{5}{|l|}{ Micro-enterprises } \\
\hline Less knowledge-intensive & $4,3 / 2,7$ & $4,3 / 1,3$ & $1,5 / 2,0$ & $3,1 / 1,5$ \\
\hline Knowledge-intensive & $8,3 / 4,7$ & $3,4 / 1,2$ & $3,1 / 2,2$ & $4,3 / 1,6$ \\
\hline \multicolumn{5}{|c|}{ Small enterprises (not including micro) } \\
\hline Less knowledge-intensive & $2,2 / 1,0$ & $3,7 / 1,0$ & $7,8 / 1,7$ & $6,2 / 1,6$ \\
\hline Knowledge-intensive & $6,1 / 1,5$ & $2,3 / 0,8$ & $12,6 / 3,1$ & $7,6 / 2,1$ \\
\hline \multicolumn{5}{|l|}{ Medium-sized enterprises } \\
\hline Less knowledge-intensive & $0,0 / 0,7$ & $4,0 / 1,5$ & $-0,5 / 2,0$ & $7,5 / 2,6$ \\
\hline Knowledge-intensive & $0,9 / 1,1$ & $2,8 / 1,1$ & $-0,1 / 1,1$ & $8,7 / 3,0$ \\
\hline \multicolumn{5}{|l|}{ Large enterprises } \\
\hline Less knowledge-intensive & $1,1 / 1,1$ & $5,0 / 1,0$ & $0,5 / 2,5$ & $6,5 / 4,9$ \\
\hline Knowledge-intensive & $3,4 / 1,7$ & $3,4 / 0,8$ & $1,9 / 0,5$ & $7,5 / 5,5$ \\
\hline
\end{tabular}

Source: European Commission. (n.d.). Annual Report on European SMEs 2018/2019. Retrieved May 15, 2020, from https://ec.europa.eu/growth/smes/business-friendly-environment/performance-review_en\#annual-report

Although micro-enterprises are in general oriented to a much lesser extent to research and development than other categories of enterprises (Barinova et al., 2019), the French micro-enterprises showed a positive dynamic, compared to the national enterprises of the other categories and micro-enterprises of some countries with a similar level of development in 2018 (Table 2).

Overall, French SMEs accumulate $17 \%$ of domestic spendings on research and development (more than $70 \%$ of which goes to the services sector, while large enterprises spend around $75 \%$ on high-technology and medium-technology industries), $24 \%$ of employment in scientific research and $24 \%$ of public financial support to research and development enterprises. ${ }^{13}$ Merely $5 \%$ of employment in research and development (68\% of which are employees in scientific research) accounts for micro-enterprises; only $3 \%$ of domestic expenditures on research and

${ }^{11}$ Les grandes entreprises pèsent plus dans le Nord et les petites dans le Sud. Retrieved June 1, 2020, from https://insee.fr/fr/statistiques/1281379\#titre-bloc-13

${ }^{12}$ Provence-Alpes-Côte d'Azur, région de prédilection des professionnels libéraux. Retrieved June 1, 2020, from https://www.insee.fr/fr/statistiques/3679058

${ }^{13}$ INSEE. (n.d.). Les entreprises en France, Édition 2019. Retrieved June 15, 2020, from https://www.insee.fr/fr/statistiques/4256020 
development is spent directly on micro-enterprises (although it represents $31 \%$ of their turnover). For comparison: SMEs (without micro-enterprises), intermediatesized enterprises and large enterprises spend 7, 3 and $2 \%$ respectively of their turnover on research and development. Micro-enterprises carry out nearly $21 \%$ of their research and development spending by means of the direct public funding and this share is growing steadily (compare: the same indicator for SMEs (without micro-enterprises) intermediate-sized enterprises and large enterprises is 9, 2 and $10 \%$ respectively). ${ }^{14}$

Government support for micro-business in France. The French government acknowledges the special role of micro-business in the French economy (Vlasova, 2015; Goffee, Scase, 2016) and expresses strong support for micro-enterprises. The state assistance falls within the framework of the common European Small Business support strategy stated in the Small Business Act for Europe (SBA) of 25 June 2008. According to SBA, it is prior to the community to promote entrepreneurship, to reduce bureaucracy, to facilitate small businesses access to finance and to bring them to international markets ${ }^{15}$ (Barinova et al., 2019; OECD, 2016). This strategy is implemented into the French Law on the Modernization of the Economy (French: Loi de modernisation de l'économie) No. 2008-776 of 4 August $2008^{16}$, which introduced the individual entrepreneur status (French: autoentrepreneur). In 2016 the individual entrepreneur status was abolished (with a transition period up to the end of 2019) and replaced by the special micro-enterprise regime created in 2014.

In order to enjoy the special regime micro-enterprise should meet the criteria. In particular, the annual turnover of enterprises, profiting from trade and commerce (purchase and sale of goods, production and sale of products and food, short-term rental of unfurnished living quarters, accommodation in specific touristic furnished facilities) (French: Bénéfices industriels et commerciaux, BIC) must not exceed 176,2 thousand euro (the micro-BIC regime); the annual turnover of enterprises with non-commercial income (i.e. from the provision of services) (French: Bénéfices non commerciaux, BNC) must not exceed 72,5 thousand euro (the micro-BNC regime). Enterprises that provide short-term rental of unfurnished living quarters must accumulate the annual turnover not exceeding 70 thousand euro. In case of mixed activity, the total turnover must not exceed 176,2 thousand euro and service sector income must not surpass 72,5 thousand euro. Besides, those members of liberal professions who are not related to the regimes of Social Security of Self-Employed Workers Fund or Inter-profession Body for Retirement Planning and Insurance (French: Caisse interprofessionnelle de prévoyance et d'assurance vieillesse, CIPAV) are excluded from micro-enterprise regime. Furthermore, an enterprise must be properly registered and have the legal status (Table 3).

${ }^{14}$ État de l'Enseignement supérieur, de la Recherche et de l'Innovation en France $n^{\circ} 12$. Retrieved June 20, 2020, from https://publication.enseignementsup-recherche.gouv.fr/eesr/FR/Recherche/

${ }^{15}$ A "Small Business Act" for Europe: EUR-lex. Retrieved June 1, 2020, from https://eurlex.europa.eu/legal-content/EN/TXT/?uri=CELEX:52008DC0394

${ }^{16}$ LOI n ${ }^{\circ} 2008-776$ du 4 août 2008 de modernisation de l'économie. Retrieved May 20, 2020, from https://www.legifrance.gouv.fr/affichTexte.do?cidTexte=JORFTEXT000019283050 
Key features of tax and social regime of micro-enterprise (as at 17 January 2020)

General conditions for 1. Allowable legal status.

inclusion in micro-enter- 2. Registration with Artisan Enterprise Register (French: Répertoire des métiers), prise regime or Company and trade register (French: Le registre du commerce et des sociétés, RCS), or Organizations for the Collection of Social Security and Family Benefit Contributions (French: Unions de Recouvrement des Cotisations de Sécurité Sociale et d'Allocations Familiales, URSSAF) (for the liberal professions) ${ }^{17}$. 3. Respect the upper limits of turnover

Conditions for exclusi- 1. Exceeding the upper limits of turnover two times for two years running. on from micro-enterprise 2 . Absence of turnovers or failure to submit turnover declaration for eight conregime secutive quarters.

3. According to micro-entrepreneur's wish

\section{TAX REGIME $^{18}$}

\begin{tabular}{ll}
\hline General & Additional \\
\hline Tax on personal income & \\
\hline
\end{tabular}

Special conditions _ _ _ Taxable revenue per each family member (considering family quotients) for the year before last must not exceed the upper limit of the second tranche fixed in the same year in order to pay tax on personal income (27 086 euro in 2018) $)^{19}$ (Komissarova, 2015)

\begin{tabular}{|c|c|c|}
\hline Tax base & Profit $^{20}$ & Turnover \\
\hline Tax rate & $\begin{array}{l}\text { Profit adds up to the other taxable } \\
\text { incomes of a household. The amount } \\
\text { received is subject to the progressive } \\
\text { income tax taking into account family } \\
\text { coefficients }\end{array}$ & $\begin{array}{l}1 \% \text { - sale of goods, production and } \\
\text { sale of products and food, accommo- } \\
\text { dation services. } \\
1,7 \% \text { - other commercial and artisanal } \\
\text { services. } \\
2,2 \% \text { - those who provide their ser- } \\
\text { vices within liberal professions }\end{array}$ \\
\hline Payment date & Annually & $\begin{array}{l}\text { Either monthly or quarterly (according } \\
\text { to taxpayer's wish) }\end{array}$ \\
\hline \multicolumn{3}{|c|}{ Value-added tax } \\
\hline $\begin{array}{l}\text { Tax exemption requi- } \\
\text { rements }\end{array}$ & \multicolumn{2}{|c|}{$\begin{array}{l}\text { The micro-BIC regime: value-added tax is not charged until the turnover of } \\
94,3 \text { thousand euro. } \\
\text { The micro-BNC regime: value-added tax is not charged until the turnover of } \\
36,5 \text { thousand euro. } \\
\text { Beyond these thresholds value-added tax is paid according to the general rules. } \\
\text { On condition that these thresholds are not exceeded value-added tax is exclu- } \\
\text { ded from the price of goods and services for the final consumer }\end{array}$} \\
\hline
\end{tabular}

${ }^{17}$ Artisan enterprise register is administered by Chamber of Artisans (Chambre de Métiers), Commercial register is administered by Chamber of Commerce and Industry.

${ }^{18}$ Above mentioned a micro-entrepreneur pays land tax from enterprises (except the first year of work) on general terms (apart from persons employed in the liberal professions).

${ }^{19}$ Taxable revenue and the upper threshold of the second tranche for 2018 are considered when paying tax for 2020 .

${ }^{20}$ Calculated by tax authorities by way of applying discount on occupational expenses to the declared turnover depending on nature of the activities: $71 \%$ for micro-business in trade and short-term (namely profit is $29 \%$ of turnover), $50 \%$ for other activities that earn industrial and commercial profit, $34 \%$ for activities that earn non-commercial profit, with a minimum deduction of 305 euro. 
Table 3, ending

\begin{tabular}{ll}
\hline & \multicolumn{1}{c}{ SOCIAL REGIME } \\
\hline Basis of assessment & Turnover ${ }^{21}$ \\
\hline Rate & $\begin{array}{l}12,8 \% \text { - sale of goods, production and sale of products and food, short-term } \\
\text { rental of unfurnished living quarters, accommodation in specific touristic fur- } \\
\text { nished facilities. } \\
\text { 22\% - service sector (including commercial, artisan and certain liberal profes- } \\
\text { sions services), short-term rental of furnished living quarters }\end{array}$ \\
\hline Payment period & Monthly or quarterly (according to taxpayer's wish) \\
\hline Basis of assessment & Turnover Contributions to the system of vocational training \\
\hline Rate & $\begin{array}{l}0,10 \% \text { - trade and services of unregulated liberal professions. } \\
0,20 \% \text { - services of regulated liberal professions. } \\
0,30 \% \text { - artisanal activity }\end{array}$ \\
\hline Payment period & Monthly or quarterly (according to taxpayer's wish) \\
\hline
\end{tabular}

Source: made by the author according to the data of the French Chamber of Industry and Commerce.

Among the main benefits of micro-entrepreneur status, the following deserve mention.

1. Streamlined bureaucratic procedures, specifically, registration and closure procedures, the order of the status of an enterprise changes (from micro-enterprise to another, etc.)

The free of charge registration can be made via the official web-site ${ }^{22}$ of Organizations for the Collection of Social Security and Family Benefit Contributions (French: Unions de recouvrement des cotisations de sécurité sociale et d'allocations familiales, URSSAF) or in a special section via the official web-site of the French Ministry of Economy and Finance. ${ }^{23}$ To terminate the entrepreneur's activity one should fill in the special form Cerfa $\mathrm{n}^{\circ} 13905^{*} 03$ and send it to the Centre for business formalities (French: Centre de Formalités des Entreprises, CFE).

2. Substantial tax relief and simplified taxation, simple tax declaration procedure and easy reporting system as a whole. Furthermore, an entrepreneur may choose one of the two variants of paying income tax (the availability of an additional regime is possible on condition of respecting the certain turnover limits).

3. Facilitated social regime (social contributions are calculated according to the turnover and paid monthly or quarterly only if the turnover data is positive).

4. Vast public financial assistance, aiming also at research and development realization.

5. Strong information support, provided foremost by Chamber of Commerce and Industry and Organizations for the Collection of Social Security and Family Benefit Contributions $^{24}$ (Barinova et al., 2019; OECD, 2016; 2017).

${ }^{21}$ Social contributions are not paid in the absence of positive turnover.

${ }^{22}$ Auto entrepreneur. (n.d.). Un service des Urssaf. Retrieved May 15, 2020, from http://autoentrepreneur.urssaf.fr/

${ }^{23}$ Guichet entreprises. Retrieved May 15, 2020, from http://guichet-entreprises.fr/

${ }^{24}$ In 2018 the organization created a special web-site (http://autoentrepreneur.urssaf.fr/) and mobile application for a convenient micro-entrepreneur management. 
Role of micro-entrepreneurship in the French economy. 1,36 million microentrepreneurs that enjoyed special tax and social regimes (42\% of self-employed persons versus $26 \%$ in 2011) were registered in France at the end of 2018. This mechanism has been proved to be attractive due to the stable positive growth dynamics of its users: if the average annual growth rate in 2011-2017 was 8,3\%, in 2018 after the twofold increase of the upper threshold of the turnover (from 82,8 to 176,2 thousand euro in the micro-BIC regime and from 33 to 72,5 thousand euro in the micro-BNC regime) it reached $15,4 \%$. It is estimated that the increase of the upper limit provided at least one quarter of the growth. ${ }^{25}$

Micro-entrepreneurs carry out their activities almost in all economic sectors. A detailed structure of their distribution by economic activities is shown in Table 4.

The table indicates that the majority of micro-enterprises functions in constructions, activities in culture and recreation, transport services, business and other management consulting, manufacturing, health care, education, hair and body care services (more than $40 \%$ of the registered entrepreneurs are occupied in these fields). The biggest growth in number of micro-entrepreneurs is registered in transport services (due to the popularity of the Internet trade and home delivery), real estate operations, cleaning services, sports activities and health care (due to alternative medicine spread).

The rate of micro-entrepreneurs with profit and registered micro-entrepreneurs varies from $40,4 \%$ in transport services to $89,2 \%$ in health care (overall it amounts to $74,6 \%$ ). According to Accosstat, this indicator is tightly linked to microenterprises functioning period: just over $54 \%$ of entrepreneurs announces about profit during the first year of work, more than $85 \%$ states the same after two years of work and $90 \%$ - after five years of work. So, the low rate of profitable enterprises in transport services can be explained by their high rotation.

Distribution of micro-entrepreneurs by gender and age as well as the ratio of registered micro-entrepreneurs and micro-entrepreneurs with profit according to the criteria is introduced in Table 5.

Men dominate among micro-entrepreneurs (60,7\%) however, enterprises, that are run by women, demonstrate a higher rate of profit $(79,6$ against $71,4 \%)$ that could be generally explained by gender-specific sectoral composition of activities within micro-enterprises. Women traditionally dominate in hair and body care services, health care and some other activities where the ratio between microentrepreneurs with profit and registered micro-entrepreneurs is relatively high. At the same time female presence is minimal in constructions, repair (excluding vehicle repair) and transport services where the above-mentioned ratio is lower than average.

With regard to the age structure of micro-entrepreneurs, it should be noted that as the age of entrepreneurs raises, the number of entrepreneurs decreases (exceptions are persons under the age of 30), while the profitability of entrepreneurs, on the contrary, grows. Thus, $86,1 \%$ of micro-entrepreneurs over the age of sixty are with profit, while the same rate of persons under thirty years old is at the level of $58 \%$.

${ }^{25}$ Acosstat. (2019, juillet). Les micro-enterpreneurs en 2018: un nouvel elan qui confirme l'attractivité $d u$ dispositive. $\mathrm{N}^{\circ}$ 289. Retrieved June 24, 2020, from https://www.acoss.fr/files/ Publications/Acoss_Stat/Acoss_stat_289.pdf 
Distribution of micro-entrepreneurs by types of economic activities in 2018

\begin{tabular}{|c|c|c|c|c|c|}
\hline \multirow{3}{*}{ Types of economic activities } & \multicolumn{4}{|c|}{$\begin{array}{l}\text { Number of registered } \\
\text { micro-entrepreneurs }\end{array}$} & \multirow{3}{*}{$\begin{array}{l}\text { Micro-entrepreneurs } \\
\text { with profit, \% of } \\
\text { the registered }\end{array}$} \\
\hline & \multirow{2}{*}{$\begin{array}{l}\text { Thous. } \\
\text { pers. }\end{array}$} & \multirow{2}{*}{$\%$ of total } & \multicolumn{2}{|c|}{ Change, \% } & \\
\hline & & & $2017 / 2011$ & $2018 / 2017$ & \\
\hline Agriculture, forestry and fishing & 2,6 & 0,2 & 7,8 & 7,8 & 83,7 \\
\hline Manufacturing & 73,7 & 5,4 & 9,9 & 11,4 & 82,9 \\
\hline Catering trade/profession & 20,5 & 1,5 & 7,6 & 5,8 & 75,9 \\
\hline Finishing works & 75,7 & 5,6 & 6,6 & 8,3 & 80,4 \\
\hline $\begin{array}{l}\text { Constructions } \\
\text { (other types of activities) }\end{array}$ & 83,9 & 6,2 & 5,8 & 9,3 & 78,9 \\
\hline Trade and auto maintenance & 30,8 & 2,3 & 10,9 & 11,9 & 64,1 \\
\hline $\begin{array}{l}\text { Wholesale and intermediate } \\
\text { trading }\end{array}$ & 37,0 & 2,7 & 9,4 & 21,0 & 62,8 \\
\hline $\begin{array}{l}\text { Retail trade of food (not including } \\
\text { catering trade/profession) }\end{array}$ & 3,3 & 0,2 & 6,6 & 11,1 & 70,7 \\
\hline Retail trade of non-food products & 45,0 & 3,3 & 4,5 & 8,3 & 74,5 \\
\hline Retail trade of unclassified products & 48,1 & 3,5 & 3,7 & 1,0 & 80,5 \\
\hline Non-specialized retail trade & 37,4 & 2,8 & $-0,1$ & 15,1 & 66,8 \\
\hline Transport services & 78,2 & 5,8 & 44,0 & 80,6 & 40,4 \\
\hline Accommodation and food service & 41,3 & 3,0 & 10,8 & 13,3 & 73,1 \\
\hline Information services & 43,8 & 3,2 & 3,1 & 11,3 & 70,6 \\
\hline Financial services and insurance & 7,4 & 0,5 & 9,2 & 20,7 & 64,9 \\
\hline Real estate operations & 25,9 & 1,9 & 15,6 & 31,0 & 60,4 \\
\hline Legal services & 1,2 & 0,1 & 2,9 & 2,5 & 83,6 \\
\hline $\begin{array}{l}\text { Accounting and consulting } \\
\text { services, engineering }\end{array}$ & 47,3 & 3,5 & 9,7 & 14,5 & 74,2 \\
\hline $\begin{array}{l}\text { Business and other management } \\
\text { consulting }\end{array}$ & 79,3 & 5,8 & 9,3 & 26,2 & 64,0 \\
\hline $\begin{array}{l}\text { Other scientific and technical } \\
\text { activities }\end{array}$ & 58,4 & 4,3 & 8,5 & 12,3 & 77,1 \\
\hline Design services & 28,4 & 2,1 & 4,1 & 13,6 & 75,2 \\
\hline Cleaning services & 38,6 & 2,8 & 14,3 & 18,4 & 78,6 \\
\hline $\begin{array}{l}\text { Other administrative and support } \\
\text { activities }\end{array}$ & 44,6 & 3,3 & 3,0 & 13,0 & 76,8 \\
\hline Education & 58,4 & 4,3 & 9,0 & 11,9 & 80,4 \\
\hline Health care & 65,9 & 4,9 & 19,3 & 12,5 & 89,2 \\
\hline Activities in culture and recreation & 93,9 & 6,9 & 11,2 & 11,9 & 78,9 \\
\hline Sports activities & 37,4 & 2,8 & 14,1 & 13,1 & 83,7 \\
\hline Repair (excluding vehicle repair) & 23,0 & 1,7 & 1,3 & 4,1 & 84,9 \\
\hline Hair and body care services & 57,1 & 4,2 & 5,3 & 9,7 & 88,8 \\
\hline Other services to individuals & 51,5 & 3,8 & 5,6 & 20,0 & 77,5 \\
\hline Others & 17,0 & 1,3 & 19,3 & 24,3 & 68,8 \\
\hline TOTAL & 1356,8 & 100,0 & 8,3 & 15,4 & 74,6 \\
\hline
\end{tabular}

Source: Acosstat. (2019, juillet). Les micro-enterpreneurs en 2018: un nouvel elan qui confirme l'attractivité du dispositive. $\mathrm{N}^{\circ}$ 289. Retrieved June 24, 2020, from https://www.acoss.fr/files/Publications/ Acoss_Stat/Acoss_stat_289.pdf 
Gender and age distribution of micro-entrepreneurs by the end of 2018

\begin{tabular}{llccc}
\hline & \multicolumn{2}{c}{$\begin{array}{c}\text { Number of registered } \\
\text { micro-entrepreneurs }\end{array}$} & $\begin{array}{c}\text { Micro-entrepreneurs } \\
\text { who are employed as well, } \\
\text { \% of the registered }\end{array}$ & $\begin{array}{c}\text { Micro-entrepreneurs } \\
\text { with profit, } \\
\text { \% of the registered }\end{array}$ \\
\cline { 2 - 3 } Thous. pers. & \% of total & & \\
\hline \multicolumn{2}{l}{ Gender distribution } & & 39,0 & 71,4 \\
\hline Male & 823,0 & 60,7 & 38,8 & 79,6 \\
\hline Female & 533,7 & 39,3 & & 57,7 \\
\hline Age distribution & & & 54,9 & 72,6 \\
\hline Under 30 years & 263,6 & 19,4 & 44,3 & 78,5 \\
\hline 30-39 years & 366,3 & 27,0 & 38,2 & 83,1 \\
\hline 40-49 years & 316,2 & 23,3 & 31,2 & 86,1 \\
\hline 50-59 years & 245,5 & 18,1 & 14,2 & 74,6 \\
\hline Over 60 years & 165,1 & 12,2 & 38,9 & \\
\hline TOTAL & 1356,8 & 100,0 & & \\
\hline
\end{tabular}

Source: Acosstat. (2019, juillet). Les micro-enterpreneurs en 2018: un nouvel elan qui confirme l'attractivité du dispositive. $\mathrm{N}^{\circ}$ 289. Retrieved June 24, 2020, from https://www.acoss.fr/files/Publications/ Acoss_Stat/Acoss_stat_289.pdf

Basically, the effective current system of state support of the micro-enterprise makes it the most suitable and convenient form to start one's own business.

\section{Conclusion}

The following conclusions could be drawn from the analysis. Micro-enterprises take an important place in the French economy by providing one fifth of the employment in the country and the same share of value added. Meanwhile, microenterprises are oriented towards export extremely weak because their activities are concentrated in the services sector and target mainly at the local markets. Moreover, while large and intermediate-sized enterprises are centered in the industrially developed regions, SMEs (including micro-enterprises) are largely oriented to the hotel and restaurant business sphere and operate mainly in the south of the country.

Micro-enterprises contribute little to research and development and remain far below the enterprises of other categories, considering the percentage of total expenditure on research and development and the percentage of total employment in scientific research sector. Besides, by spending almost one third of its turnover on researches and considering the share of direct financial assistance from the state in total expenditures on scientific researches, micro-business is an absolute leader in terms of research and development intensity. Another important feature of research and development is that micro-business provide a high degree of its concentration in the service sector (unlike large enterprises that conduct researches mainly in high and medium technology branches of industry).

To date, a sufficiently effective system of public support to micro-business has been formed in France. Apart from providing financial assistance, the system includes substantial tax benefits and simplified taxation schemes, easy reporting system and simple procedures for filing tax return, facilitated social regime, simplification of major bureaucratic formalities and strong information support in all stages of functioning of an enterprise. 


\title{
References
}

Arlotto, J., Cyr, A., Meier, O., \& Pacitto, J.-C. (2011). Très petite entreprise et croissance: À la découverte d'un continent inexploré. Management \& Avenir, (43), 16-36.

Barinova, V.A., Zemcov, S.P., Knobel', A.Yu., \& Loshchenkova, A.N. (2019). Malyj i srednij biznes kak faktor ekonomicheskogo rosta Rossii [Small and Mid-Sized Business as a Factor of Economic Growth in Russia]. Moscow, Gaidar Institute for Economic Policy. (In Russ.)

Goffee, R., \& Scase, R. (2016). Entrepreneurship in Europe. The Social Process. Routledge (Routledge Revivals).

Komissarova, Zh.N. (2015). Nalogovaya sistema Francii [French Tax System]. Mirovoe i nacional'noe hozyajstvo [World and National Economy], 2(33), 24-33. (In Russ.)

Kushnir, K., Mirmulstein, M., \& Ramalho, R. (2010). Micro, Small, and Medium Enterprises around the World: How Many Are There, and What Affects the Count? World Bank Group.

Marniesse, S. (2000). Analyse des disparitions de microentreprises à l'aide d'un modèle probit et d'un modèle de durée. Paris.

OECD. (2016). Financing SMEs and Entrepreneurs 2016: An OECD Scoreboard.

OECD. (2017). Small, Medium, Strong. Trends in SME Performance and Business Conditions.

Vlasova, N.L. (2015). Rol' i mesto malogo i srednego biznesa $v$ nacional'noj ekonomike $v$ sovremennyh usloviyah [The Role and Position of Small and Medium-sized Enterprises in the National Economy in Contemporary Environment]. Moscow. (In Russ.)

Zakharova, N.V., \& Labudin, A.V. (2017). Maloe i srednee predprinimatel'stvo v evropejskih stranah: Osnovnye tendencii razvitiya [Small \& Medium Entrepreneurship in European Countries: Main Tendencies of the Development]. Upravlencheskoe konsul'tirovanie [Administrative Consulting], (2), 64-77. (In Russ.)

\section{Article history:}

Received: 30 June 2020

Revised: 1 August 2020

Accepted: 31 August 2020

\section{For citation:}

Komissarova, Zh.N. (2020). Micro-business in France: specificity, role in the national economy, system of state support. RUDN Journal of Economics, 28(4), 765-777. http://dx.doi.org/ $10.22363 / 2313-2329-2020-28-4-765-777$

\section{Bio note:}

Zhanna N. Komissarova, $\mathrm{PhD}$ in Economics, Associate Professor at the World Economy Department of the Moscow State Institute of International Relations (University) of the Ministry of Foreign Affairs of Russia (MGIMO University). E-mail: Jeanne.25@mail.ru

\section{Микробизнес во Франции: специфика, роль в национальной экономике, система государственной поддержки}

\section{Ж.Н. Комиссарова}

\author{
Московский государственный институт международных отношений (университет) \\ МИД России \\ Российская Федераџия, 119454, Москва, пр-кт Вернадского, 76
}

Аннотация. Деятельность микробизнеса существенно влияет на состояние экономики и социальной сферы любой страны. Французский образец примечателен тем, что стране, которая давно стремилась к развитию больших групп, только за два десятилетия 
удалось построить успешную систему государственной поддержки микробизнеса, включающую как конкретные, так и общие меры для малых и средних предприятий. В исследовании сделана попытка выявить современные тенденции развития микробизнеса во Франции, а также проанализировать эффективность системы государственной поддержки деятельности рассматриваемой категории хозяйствующих субъектов. В зависимости от характера предмета исследования автор использовал такие методы и подходы научного познания, как индукция и дедукция, анализ и синтез, системно-структурный, сравнительный и статистический анализ. В исследовании подробно анализируются текущие тенденции развития микробизнеса во Франции, включая его отраслевую и региональную специфику, оценивается вклад микропредприятий в экономическое и социальное развитие страны и глубоко исследуется система государственной поддержки. Микропредприятия занимают важное место во французской экономике, обеспечивая пятую часть рабочих мест в стране и такую же долю добавленной стоимости. Между тем микропредприятия довольно слабо ориентированы на экспорт, поскольку их деятельность нацелена в основном на местные рынки и сосредоточена в секторе услуг. Микропредприятия мало вносят вклад в исследования и разработки (с учетом процента общих расходов на исследования и разработки и процента от общей занятости в секторе научных исследований). Однако микробизнес остается безусловным лидером по интенсивности исследований и разработок, тратя почти треть своего оборота на исследования и учитывая долю прямой финансовой помощи государства в общих расходах на научные исследования. На сегодняшний день во Франции сформирована достаточно эффективная система государственной поддержки микробизнеса. Помимо финансовой помощи, система включает существенные налоговые льготы и упрощенные схемы налогообложения, удобную систему отчетности и простые процедуры подачи налоговой декларации, упрощенный социальный режим, упрощение основных бюрократических формальностей и надежную информационную поддержку на всех этапах функционирования предприятия.

Ключевые слова: экономика Франции, микропредприятия, роль микробизнеса в национальной экономике, система государственной поддержки микробизнеса, режим микропредприятия, освобождение от налогов

\section{История статьи:}

Дата поступления в редакцию: 30 июня 2020 г.

Дата проверки: 1 августа 2020 г.

Дата принятия к печати: 31 августа 2020 г.

\section{Для цитирования:}

Komissarova Zh.N. Micro-business in France: specificity, role in the national economy, system of state support // Вестник Российского университета дружбы народов. Серия: Экономика. 2020. T. 28. No. 4. C. 765-777. http://dx.doi.org/10.22363/2313-2329-2020-284-765-777

\section{Сведения об авторе:}

Комиссарова Жанна Николаевна, кандидат экономических наук, доцент кафедры мировой экономики Московского государственного института международных отношений (университета) МИД России. E-mail: Jeanne.25@mail.ru 